\author{
Łukasz Chyla* \\ ORCID: 0000-0001-7353-8125 \\ Jagiellonian University \\ University of Warsaw
}

DOI: $10.19195 / 1733-5779.29 .7$

\title{
The devil is in the details: Regulation EU 2017/1129**
}

\section{JEL Classification: G14, G15, K33}

Keywords: prospectus obligations, Prospectus Regulation, Regulation EU 2017/1129

Słowa kluczowe: obowiązki prospektowe, rozporządzenie prospektowe, rozporządzenie UE $2017 / 1129$

\begin{abstract}
On 21 July 2019, the prospective Prospectus Regulation (EU) 2017/1129 effectively came into force, replacing the previous Prospectus Directive. Its main goals are to increase effective investor protection and to reduce barriers and burdens for issuers, especially smaller ones. In addition to flagship reforms, such as raising the prospectus exemption thresholds and introducing new, alleviated types of prospectuses, the Regulation introduces a number of controversial changes, such as limiting the concept of private offers, extending the scope of the "wholesale prospectus," creating a prospectus summary modeled on a key information document known from PRIIPS and reforming risk factors. Seemingly less prominent, these changes can nonetheless have a significant impact on issuers and investors in the European Union. The purpose of this article is to analyze and evaluate selected changes introduced by the new prospectus law.
\end{abstract}

\section{Diabeł tkwi w szczegółach. Rozporządzenie UE 2017/1129}

Abstrakt: 21 lipca 2019 roku weszło w życie rozporządzenie prospektowe (UE) 2017/1129, które zastąpiło obowiązującą do tej pory dyrektywę prospektową. Jego główne cele to zwiększenie efektywnej ochrony inwestorów oraz redukcja barier i obciążeń dla emitentów - szczególnie tych mniejszych. Oprócz flagowych reform, takich jak podniesienie progów zwolnienia z obowiązku publikacji prospektu emisyjnego czy wprowadzenie nowych rodzajów prospektów emisyjnych, rozporządzenie wprowadza liczne kontrowersyjne zmiany, między innymi ograniczenie pojęcia ofert

* Scientific Tutor (Opiekun naukowy) — prof. dr hab. Andrzej Szumański

** The article was written as part of the Polish National Center for Science scientific grant "Preludium" — No. 2018/29/N/HS5/02977. 
prywatnych, rozszerzenie zakresu ,prospektów hurtowych”, stworzenie podsumowania prospektowego na wzór kluczowego dokumentu informacyjnego znanego z PRIIPS oraz reformę czynników ryzyka. Te z pozoru mniej wyeksponowane zmiany mogą mieć istotny wpływ na emitentów i inwestorów w Unii Europejskiej. Celem artykułu jest analiza i ocena wybranych zmian wprowadzonych przez nowe prawo prospektowe.

\section{Introduction}

The 2015 Impact Assessment Working Paper ${ }^{1}$ evaluation identified numerous issues which seemed to hinder the efficiency of the EU capital markets. The costs of compliance with the previous prospectus law and disclosure requirements were extremely high (on average at EUR 1 million, and up to $15 \%$ of the capital raised), ${ }^{2}$ investor protection was perceived as ineffective ${ }^{3}$ because of the information overload, the regulatory framework under Prospectus Directive ${ }^{4}$ was neither flexible nor suitable for SMEs as well as some types of securities. ${ }^{5}$

To address these issues, the new prospectus regime was introduced by the Prospectus Regulation (EU) 2017/11296 (hereinafter referred to as "PR"). This new prospectus law, which replaced the previous Prospectus Directive (hereinafter referred to as "PD") is directly binding and fully applicable in all EU Member States from 21 July 2019. The new legislation is a realization of the European Capital Markets Union Plan (hereinafter referred to as "CMU"), ${ }^{8}$ the flagship EU project

${ }^{1}$ European Commission, The Commission Staff Working Document Impact Assessment accompanying the document Proposal for a Regulation of the European Parliament and of the Council on the prospectus to be published when securities are offered to the public or admitted to trading, Brussels, 30.11.2015.

2 Ibidem, pp. 8-9.

3 Ibidem, p. 9.

${ }^{4}$ Directive 2003/71/EC of the European Parliament and of the Council of 4 November 2003 on the prospectus to be published when securities are offered to the public or admitted to trading and amending Directive 2001/34/EC (OJ L 345, 31.12.2003, p. 64).

${ }^{5}$ Ibidem, p. 9.

${ }^{6}$ Regulation (EU) 2017/1129 of the European Parliament and of the Council of 14 June 2017 on the prospectus to be published when securities are offered to the public or admitted to trading on a regulated market, and repealing Directive 2003/71/EC (OJ L 168, 30.6.2017, pp. 12-82).

7 The Prospectus Regulation (2017/1129) was published in the Official Journal on 30 June 2017 and came into force on 20 July 2017. However, the vast majority of its provisions will have effect from 21 July 2019. Articles 1(5)(a)(b)(c) and 1(5) subparagraph 2 are subject to an earlier application date than the majority of the provisions of the Prospectus Regulation and became applicable on 2 July 2017 (prospectus exemption for the admission to trading of additional securities of the same class as, and amounting to $20 \%$ of the number of, those already admitted to the same regulated market). Articles 1(3) and 3(2) are subject to an earlier application date than the majority of the provisions of the Prospectus Regulation and became applicable on 21 July 2018 (exemption thresholds below which prospectus is not required).

${ }^{8}$ Capital Markets Union - Communication of the Commission of 30 September 2015, entitled Action Plan on Building a Capital Markets Union; European Commission, The Commission Staff Working Document Impact Assessment..., Brussels, 30.11.2015, Annex 3, p. 6. 
which reflects a long-term ambition to expand and diversify sources of funding alternative to bank lending, and to help EU companies to better finance their expansion and therefore to create jobs and growth. ${ }^{9}$ The regulation is also part of the European Commission's (hereinafter referred to as "EC") more general commitment to simplifying EU laws and making them more efficient (REFIT). ${ }^{10}$

The main aim of the PR is to ensure investor protection and market efficiency while enhancing the internal EU market for capital. ${ }^{11}$ To achieve this goal, the Regulation 2017/1129 introduces a number of widely praised flagship changes, including, in particular, the form of the EU regulation, and prospectus exemption thresholds. It also introduces new institutions (e.g., Universal Registration Document) and completely new types of prospectuses (EU Growth Prospectus, prospectus for secondary issuances). However, these issues are outside of the scope of this article. ${ }^{12}$

In addition to the said reforms, the Regulation introduces several less laudable and more controversial changes, such as limiting the concept of private offers, extending the scope of application of the "wholesale prospectus," creating a prospectus summary modeled on a key information document known from PRIIPS and reforming the risk factors section. While these changes may seem less prominent or even minor, they can nonetheless have a significant impact on issuers and investors in the European Union. The purpose of this article is to present the background for these selected changes, as well as to analyze and evaluate them.

\section{The barely noticed end of private offerings?}

The 2017 Prospectus Regulation expands the notion of public offering in a way that raises concerns. Offerings previously meant as private, are now considered public - although they can still benefit from prospectus exemptions under the PR. The wording of the PD indicates that it does not apply to "offers" of less than EUR 5 million $^{13}$ and that there is a prospectus exemption for certain types of "offers"14 (the "qualified investors exemption," or the "150 persons exemption" etc.). However, under Article 4 there is a prospectus exemption for "offers to the public" of some specific types of securities (shares issued in exchange for pre-existing shares of the same class etc.). According to A. Pietracosta, even though the terms

\footnotetext{
${ }^{9}$ Recital (1) of the PR.

10 The European Commission's regulatory fitness and performance (REFIT) programme, https:// ec.europa.eu/info/law/law-making-process/evaluating-and-improving-existing-laws/refit-makingeu-law-simpler-and-less-costly_en (accessed: 20.06.2019).

${ }^{11}$ Recital (7) of the PR.

${ }^{12}$ For more about this subject, see $€$. Chyla, "New prospectus regime: A critical analysis of chosen key changes," Studenckie Prace Prawnicze, Administratywistyczne i Ekonomiczne 28, 2019.

${ }^{13}$ Article 1(2)(h).

${ }^{14}$ Article 3(2).
} 
"private offerings" or "private placements" do not appear in the PD, the distinction between private and public offers is a result of the above provision. ${ }^{15}$ This view, which states that private placement is not a subcategory of a public offering, but an independent institution, seemed to be prevailing in many MS, ${ }^{16}$ such as Belgium, France, Germany, Italy, Poland, Portugal or Spain. ${ }^{17}$ Even though, according to the PD definition, the "offer of securities to the public means a communication to persons in any form and by any means..." without any particular minimum threshold referring to a number of persons involved, the nature of directive has left some room for interpretation to the MS. The word "persons" might only suggest that an offer made to a single person lies outside the scope of the public offering.

The PR ends this controversy by removing the difference between private placement and exempted public offerings. It consequently uses the term "public offerings" when it comes both to smaller offerings beyond the scope of its application ${ }^{18}$ and certain offerings exempted from prospectus obligation. ${ }^{19}$ This notion of an omnipresent public offering can also be inferred from the recitals (12), (13), (20) and (25) of the PR. ${ }^{20}$ Another argument for such critical change is the fact that the definition of public offering from Article 2(d) - although this has not been changed - incorporates the binding force of the Regulation.

This significant change eradicates an independent concept of private offering or private placement by de facto incorporating private offers under the broad notion of the public offer. The clear advantage of this solution is the harmonization of the systems within the EU, and putting an end to the previous dualistic system, practically present under the PD. On the other hand, however, this can lead to uncertainty and confusion among at least several MS, which have to revisit their national systems in order to introduce such a change. For example in Poland, under the initial proposal of the new Polish Act on Public Offering, ${ }^{21}$ no offerings exempted from prospectus obligations were considered public offerings. This provision has only been altered after it became clear that it contradicts the wording of the PR.

15 A. Pietrancosta, A.M. des Grottes, "Has the notion of 'private offerings' been abolished by the prospectus regulation of 14 june 2017?," Bulletin Joly Bourse 2018, no. 1, p. 2, https://ssrn.com/ abstract=3124225 or http://dx.doi.org/10.2139/ssrn.3124225 (accessed: 1.08.2019).

16 Ibidem, p. 3.

17 In contrast, in countries like the UK, Luxembourg and Sweden, the private placement is nothing but an exempted public offer.

18 According to Article 1(3), that the Regulation does not apply to a "public offering" of total consideration under EUR 1 million.

19 Under Article 1(4), the obligation to publish a prospectus does not apply to offers intended for "qualified investors," less than 150 persons, offers with a minimum entry ticket of EUR 100,000, with denomination per unit of at least EUR 100,000.

20 A. Pietrancosta, A.M. des Grottes, op. cit., p. 4.

21 Act amending the Polish Act of 29 July 2005 on Public Offering, the Conditions Governing the Introduction of Financial Instruments to Organised Trading, and on Public Companies. 
Moreover, this "subtle" change might have a ground-breaking impact on the other laws of the national legal systems (such as civil law, commercial law etc.), especially where the notion of public offering is used to define the scope of operational freedom, where it triggers some additional obligations for commercial companies or even bars private entities from certain actions. ${ }^{22}$ It is not hard to imagine how it might result in the confusion of regulators and stakeholders.

Besides, this change is questionable from the standpoint of principles, as it strips European issuers of the fundamental freedom to raise funds via private offers in certain cases, and grants them a mere exemption from the obligation to publish a prospectus, instead. ${ }^{23}$ It also significantly reduces the MS discretion as to what they consider private placement under their national laws. In the future, it could prove to be a matter of an unnoticeable amendment for EU lawmakers to manipulate the scope of exemptions.

Finally, this change seems to be a sudden departure from the system known in the US, where Section 4(a)(2) of the Securities Act exempts from registration duty transactions not involving any public offering. Companies conducting an offering can raise an unlimited amount of money and can sell securities to an unlimited number of accredited investors. ${ }^{24}$ However, to enjoy this safe harbor, no general solicitation or advertising is allowed and securities may not be sold to more than 35 non-accredited investors.

\section{The Wholesale Prospectus}

The problem of favorable treatment of issuers of debt securities with a high denomination per unit was broadly discussed before the implementation of the PR. Under Article 3(2)(d) of the PD, there was a full prospectus exemption granted to offers of securities with a denomination per unit amounting to at least EUR $100,000 .^{25}$ Although available to both equity and non-equity securities, it was practically used only for the latter.

At the same time, according to Article 7(2)(b) of the PD, in case of offers and admissions to trading on a regulated market of non-equity securities, the information required in a prospectus shall be appropriate from the point of view of the investors concerned for non-equity securities having a denomination per unit of at least EUR 100,000. This provision was reflected by the Implementing Regulation No 809/2004 which created a two-tier disclosure regime: a stricter one for socalled retail prospectuses for debt securities with a denomination per unit below

22 On the example of French law: A. Pietrancosta, A.M. des Grottes, op. cit., p. 7.

23 Ibidem, p. 6.

24 Rule 506(b) of Regulation D provides objective standards that a company can rely on to meet the requirements of Section 4(a)(2) exemption.

25 Raised from EUR 50,000 by Directive 2010/73/EU. 
EUR $100,000^{26}$ and a more relaxed one, for so-called wholesale prospectuses in case of securities exceeding this threshold. ${ }^{27}$ The alleviations for the wholesale prospectus under PD include no summary, greater language flexibility and reduced scope of information provided in the prospectus.

There were 2 major arguments behind the EUR 100,000 threshold for the wholesale prospectus. The first was to discourage retail investors from purchasing those securities, assuming that investors in the market for such securities have sufficient means to protect themselves and assure they are making an informed investment decision without full-blown disclosure requirements, and thus, they should be treated as professional or qualified investors. Secondly, the alleviated disclosure regime lowered issuers' administrative burdens, saved time and lowered cost, encouraging issuers to actively seek funding in the EU and strengthen the corporate bond markets. Therefore, this solution was primarily considered as a win-win.

Unfortunately, the contrast between retail and wholesale disclosure regimes incentivized issuers to make a shift from small to large denominations, ${ }^{28}$ which in turn hindered the liquidity of secondary markets, making them inaccessible for non-qualified investors and effectively stripped them of options to put their savings to productive use. This is also partly due to the fact that issuers have no trouble finding institutional investors in the EU, while the EU retail investor market is severely underdeveloped when compared to the US counterpart. ${ }^{29}$ The EUR 100,000 threshold, triggering the lighter prospectus regime or full prospectus exemption (depending on whether the securities were to be admitted to trading on a regulated market) has altered the tactics of the non-equity issuers to the extent that some of the EU and US companies, at the same time, issued similar securities in USD, EUR and GBP, which differed only in denominations per unit. ${ }^{30}$ Whereas European bonds minimum denomination was inaccessible to non-qualified investors, the US bonds minimum denomination was around USD 1,000.

26 See: Annexes IV \& V.

27 See: Annexes IX \& XIII.

28 After the Directive 2003/71/WE entered into application in 2005 (establishing the initial EUR 50,000 threshold) there was a significant increase in the share of EU bonds with a denomination between EUR 50,000 and EUR 100,000 (from 15\% to 50\%). When Directive 2010/73/EU (raising the said threshold to EUR 100,000) there was, in turn, a steep increase in the share of EU bonds with a denomination above EUR 100,000 (from 10\% to $70 \%$ ). In consequence, less than $30 \%$ of bonds listed in the EU were in denominations below EUR 100,000. See S. Çelik, G. Demirtaş, M. Isaksson, "Corporate bonds, bondholders and corporate governance," OECD Corporate Governance Working Papers 2015, no. 16.

29 See N. Moloney, E. Ferran, J. Payne (eds.), The Oxford Handbook of Financial Regulation, Oxford 2015, p. 375.

30 European Commission, The Commission Staff Working Document Impact Assessment..., Brussels, 30.11.2015, p. 30. 
To address these issues, and to restore balance and liquidity on the secondary markets several solutions were discussed,${ }^{31}$ including:

a) the lowering of the EUR 100,000 threshold of Article 3(2)(d) to a level between EUR 10,000 and EUR 50,000;32

b) removing the threshold; ${ }^{33}$

c) unifying the dual disclosure regime of Article 7(2)(b) (for non-equity securities admitted to trading on a regulated market).

Eventually, none of these scenarios has materialized. Instead, the EU lawmakers have decided to retain the EUR 100,000 denomination per unit prospectus exemption (now located in Article 1(4)(c) of the $\mathrm{PR}^{34}$ ) and more importantly, extend the relaxed disclosure regime to all non-equity securities, provided that they are traded only on a regulated market, accessible exclusively to qualified investors, ${ }^{35}$ with no resale option to non-qualified investors. The special wholesale prospectus alleviations are specified in Annexes 7, 15 of the Delegated Regulation. ${ }^{36}$ Such relaxed treatment comprises minimum information requirements, no requirement to include a summary in the prospectus, and more flexible language requirements. ${ }^{37}$

This solution is expected to contribute to the development of the qualified investor-only regulated markets in the EU, ${ }^{38}$ such as the Italian Professional Segment of the Electronic Bond Market, ${ }^{39}$ Professional Segment of the Luxembourg Stock

${ }^{31}$ Ibidem, p. 31.

32 It is questionable whether this option would have a desired impact on the market liquidity, it would nonetheless visibly diminish the investors' protection.

${ }^{33}$ This option could potentially lead to the considerable outflow of funds from the already underdeveloped EU corporate bonds regulated markets, either to multilateral trading facilities or to other jurisdictions. However, it has to be noted, that the negative effect of such solution would be partially mitigated by the fact that the issuers could still make use of other exemptions, such as the exemption of Article 3(2)(a) ("qualified investors exemption") or Article 3(2)(c) ("a minimum entry ticket exemption").

${ }^{34}$ See also Recital 20.

35 According to Articles 6(1)(d) and $13(1)(2)(a-b)$ relaxed information treatment shall be granted in case of non-equity securities which have a denomination per unit of at least EUR 100,000 or are to be traded only on a regulated market, or a specific segment thereof, to which only qualified investors can have access.

${ }^{36}$ Commission Delegated Regulation (EU) 2019/980 of 14 March 2019 supplementing Regulation (EU) 2017/1129 of the European Parliament and of the Council as regards the format, content, scrutiny and approval of the prospectus to be published when securities are offered to the public or admitted to trading on a regulated market, and repealing Commission Regulation (EC) No 809/2004.

${ }^{37}$ Recital (21).

38 R.S. Panasar et al., "The new prospectus regulation - the story so far," Cleary Gottlieb Alert Memorandum 7.03.2019, pp. 3-4.

${ }^{39}$ See https://www.borsaitaliana.it/obbligazioni/motprofessionale/motprofessionale.en.htm (accessed: 20.07.2019). 
Exchange $^{40}$ or the Professional Securities Market of the London Stock Exchange. ${ }^{41}$ While it will strengthen the liquidity of the professional secondary markets, it might also deepen the problem of illiquidity on the retail secondary markets.

\section{Prospectus summary}

The investor protection under PD was deemed ineffective, ${ }^{42}$ partly due to the problem of information overload. ${ }^{43}$ According to the Working Paper, ${ }^{44}$ the prospectuses were often drafted with the objective to address any potential legal liability rather than to provide investors with relevant and concise information, which undermined the effectiveness of investors protection. In this regard, the prospectus summary, ${ }^{45}$ reformed by the Prospectus Directive II (Directive 2010/73/ EU), has been criticized for failing to meet its purpose. The summary, which was intended to provide investors with a simple way to understand information about the product, was considered too long, unreadable, technical, unwieldy and too comprehensive ${ }^{46}$ - resulting in investor dissatisfaction. The respondents to the public consultations ${ }^{47}$ pointed to the fact that the average summary was complicated, hard to digest, while its format does not give enough flexibility to issuers to focus their summary on the key information retail investors really need. According to the PD Review, ${ }^{48}$ the average summary was full of legal jargon and often nothing but a "cut and paste" of various parts of the prospectus in order to limit potential liability risk of the issuers. Therefore, paradoxically, the summary was nothing but an excessive burden for the issuers which, at the same time, undermined the investor protection.

To address this issue, and to make summaries more qualitative, accessible and investor-friendly, the PR introduces some important changes.

40 See https://www.bourse.lu/professional-segments (accessed: 20.07.2019).

${ }^{41}$ See https://www.londonstockexchange.com/companies-and-advisors/psm/home/psm.htm (accessed: 20.07.2019).

42 European Commission, The Commission Staff Working Document Impact Assessment..., Brussels, 30.11.2015, p. 19.

43 T.M.J. Möllers, E. Kernchen, "Information overload at the capital market," Europa e Diritto Privato 2010, no 4; Behavioral Patterns and Pitfalls of U.S. Investors, A Report Prepared by the Federal Research Division, Library of Congress under an Interagency Agreement with the SEC, August 2010, pp. 1-20.

44 European Commission, The Commission Staff Working Document Impact Assessment..., Brussels, 30.11.2015, p. 9.

${ }^{45}$ See the prescriptive modular approach of Annex XXII of Regulation No 809/2004.

46 According to Article 24(1) of the Prospectus Directive "the length of the summary [...] shall not exceed $7 \%$ of the length of a prospectus or 15 pages, whichever is the longer," which in practice can amount to even 30 pages.

${ }^{47}$ Public consultations during the Expert Group of the European Securities Committee (EGESC).

${ }^{48}$ See ESME's report on Directive 2003/71/EC of September 2007, pp. 10-11, http://ec.europa. eu/internal_market/securities/docs/esme/05092007_report_en.pdf (accessed: 1.08.2019). 
- The summary should be the introduction to the prospectus, consistent with its other parts ${ }^{49}$ providing key information for investors. ${ }^{50}$ It shall be written in a concise, understandable manner, easy to read, clear, non-technical, and comprehensible for investors. ${ }^{51}$ The summary possible to be understood by everybody ${ }^{52}$

- acronyms, legalese or over-technical terms should be replaced by simple terms.

- There is a new requirement that the content of the summary must be accurate, fair and not misleading.

- The format and content of the summary are based on the KID under the PRIIPS Regulation and consists of the 4 sections: ${ }^{53}$ an introduction (containing warnings), and key information on the issuer, securities, and offer/admission. To ensure its uniform structure, the summary contains general sections and user-friendly headings ${ }^{54}$ with indicative contents and narrative descriptions. ${ }^{55}$ Importantly, if particular debt securities fall under the scope of both Prospectus Regulation and Regulation (EU) No 1286/2014, substitution in the summary of the contents of the KID is allowed, or even required, if the laws of individual Member States provide such a requirement. ${ }^{56}$ In theory, there are several aims for this original solution. ${ }^{57}$ First, to adapt the summary to the investors' needs so they can easily find the relevant information and compare various investment products as the KID-like summary forces issuers to keep the document focused on the relevant information. The KID-like summary would also likely reduce issuers' costs - especially in the case of SMEs — because of its structured form. Moreover, for authorities, it will be easier to quickly revise the summaries.

- The summary shall be a maximum of $7 \mathrm{~A} 4$ pages long ${ }^{58}$ which makes it considerably shorter and thus, easier for investors to analyze (under PD, the summaries had often 20-30 pages). A shorter summary will be also cheaper to write

49 Article 7(2) of the PR.

50 Article 7(1) of the PR.

51 Article 7(3) of the PR.

52 European Commision, The Commission Staff Working Document Impact Assessment..., Brussels, 30.11.2015, p. 45.

53 Article 7(4) of the PR.

54 In particular: "Who is the issuer of the securities?", "What is the key financial information regarding the issuer?", "What are the key risks that are specific to the issuer?", "What are the main features of the securities?", "Where will the securities be traded?", "What are the key risks that are specific to the securities?", "Why is this prospectus being produced?".

55 Recital (31) of the PR.

56 Article 7(7)(2), see also: Recital (32) of the PR.

57 European Commission, The Commission Staff Working Document Impact Assessment..., Brussels, 30.11.2015, p. 39.

58 Article 7(2). 
and translate for issuers and less troublesome for the authorities to proceed. ${ }^{59}$ However, this solution hinders flexibility for issuers, who will struggle to present all the relevant information. ${ }^{60}$

- The summary can contain only a maximum of 15 material risk factors, ${ }^{61}$ which is an attempt to stop the issuers' practice of including many non-material risk factors, in order to reduce their civil liability in case of investors loss. However, this again limits the flexibility of issuers and exposes them to the risk of being frivolously sued en masse by the investors making use of the "ex-post" investor protection. Because of liability concerns, limiting the number of risk factors in the summary to only 15 is one the most controversial changes of the PR. Even though the PR introduces a specific liability regime for summaries, ${ }^{62}$ which protects issuers, issuers might be vulnerable in other jurisdictions in case a material risk factor, present in the main prospectus body, was not included in the summary. ${ }^{63}$

- The summary shall include a selection of the issuer's historical key financial information ${ }^{64}$ which should provide investors with an overview of the issuer's assets, liabilities and profitability, relevant enough to make a preliminary assessment of the financial performance. ${ }^{65}$ To reduce issuers' discretion in this area, ${ }^{66}$ and to ensure the relevance of the information delivered to investors, the Commission adopted the regulatory technical standards ${ }^{67}$ (mostly based on the ESMA's final report on the draft regulatory standards ${ }^{68}$ ). According to the Delegated Regulation, key financial information consists of the income statement, the balance sheet, and the cash flow statement. Additionally, the Regulation identifies a limited number of disclosure requirements ${ }^{69}$ specifies the format and content of the key information, depending on different types of issuers and securities. ${ }^{70}$ In order to provide a clear picture of their financial position and avoid misleading investors, issuers

59 European Commission, The Commission Staff Working Document Impact Assessment..., Brussels, 30.11.2015, p. 39.

${ }^{60}$ R.S. Panasar et al., op. cit., p. 10.

${ }^{61}$ Article 7(10) of the PR.

62 According to Article 11(2), Member States shall ensure that no civil liability attaches to any person solely on the basis of the summary, including any translation thereof, unless it is misleading, inaccurate or inconsistent, when read together with the other parts of the prospectus, or it does not provide, when read together with the other parts of the prospectus, key information in order to aid investors when considering whether to invest in such securities. See also Recital (33).

${ }^{63} \mathrm{https} / /$ www.nortonrosefulbright.com/en/knowledge/resources-and-tools/capital-marketsunion/prospectus-regulation (accessed: 1.08.2019).

${ }^{64}$ Article 7(6)(b) of the PR.

65 Recital (1), Commission Delegated Regulation (EU) 2019/979 of 14 March 2019.

${ }^{66}$ R.S. Panasar et al., op. cit., p. 10.

${ }^{67}$ Commission Delegated Regulation (EU) 2019/979 of 14 March 2019.

68 Published in July 2017 (the "Draft RTS").

69 See Articles 2-8, Annexes I-VI, Commission Delegated Regulation (EU) 2019/979 of 14 March 2019.

${ }^{70}$ Recital (1), Commission Delegated Regulation (EU) 2019/979 of 14 March 2019. 
can include specific additional disclosures, including alternative performance measures, ${ }^{71}$ on condition that these figures are not given more prominence in the prospectus than the figures extracted from the historical financial information. ${ }^{72}$ Although alternative performance measures can yield some flexibility (especially in case of a complex financial history ${ }^{73}$ ), the rigorous itemization of the prescriptive disclosure can be worrying for many issuers, who once again have no sufficient autonomy in presenting the desired narrative of their position, and still can be held liable if they do not perfectly fit in the format.

- Importantly, the PR no longer requires a summary in the case of the wholesale prospectus regime ${ }^{74}$ and in the case of base prospectuses for debt issuance programs. ${ }^{75}$ However, some concerns were raised that market practice will force issuers to include an introductory section to the base prospectus nevertheless. ${ }^{76}$

As under the PD, the summary shall not contain cross-references to other parts of the prospectus or incorporate information by reference, which many consider an incomprehensible restriction. ${ }^{77}$ As long as the summary meets the requirements of being concise and easily understandable, I can see no reason for excluding such an opportunity, which, in fact, could be beneficial for the investors.

Under the PR, Member States have discretion with regards to certain aspects of the summary. They can increase the page limit, substitute content requirements for summaries and require reusing KID in the summary. The advantage of this additional national flexibility might be outweighed by the fragmentation and creation of numerous varying requirements which will make summaries hard to compare for investors. $^{78}$

${ }^{71}$ According to Article 1(3) Commission Delegated Regulation (EU) 2019/979 of 14 March 2019, alternative performance measures shall be financial measures of historical or future financial performance, financial position or cash flows, other than financial measures defined in the applicable financial reporting framework. See also: ESMA's Guidelines on Alternative Performance Measures.

72 Recital (3), Commission Delegated Regulation (EU) 2019/979 of 14 March 2019.

73 R.S. Panasar et al., op. cit., p. 11.

${ }^{74}$ Where the prospectus relates to the admission to trading on a regulated market of non-equity securities provided that: a) such securities are to be traded only on a regulated market, to which only qualified investors can have access, b) such securities have a denomination per unit of at least EUR 100,000. See Article 7(1)(2).

75 A summary specific to the individual issue shall only be drawn up once the final terms are included in the base prospectus see Article 8(8-9). The coexistence of two summaries (base prospectuses one and the final terms one), was criticized for putting excessive burdens on issuers, making final terms over-complicated and summaries in base prospectuses unreadable by investors. see European Commision, The Commission Staff Working Document Impact Assessment..., Brussels, 30.11.2015, p. 46.

${ }^{76}$ S. Bullock et al., New Prospectus Regulation: An Evolving Regime, Ashurst LLP Paper, 2017 Thomson Reuters (Professional) the UK.

77 A. Casale, M. Bianchi, P. Spatola, "The new prospectus regulation: A missed opportunity?," Oxford Business Law Blog 2017, https://www.law.ox.ac.uk/business-law-blog/blog/2017/03/newprospectus-regulation-missed-opportunity (accessed: 1.08.2019).

$78 \mathrm{https}$ ///www.nortonrosefulbright.com/en/knowledge/resources-and-tools/capital-marketsunion/prospectus-regulation (accessed: 1.08.2019). 
It is quite regrettable that the proposal of a fully free form summary was abandoned. ${ }^{79}$ Under this proposal, the only directives for the issuers would be: the limited number of pages, determined key sections and the general principle that information should be presented in a fair, balanced and understandable way. Although this solution would be convenient for the issuers (especially SMEs), giving them an opportunity to present their own business in a more narrative style, the prevailing argument was that it would be difficult for the authorities and investors to compare them and time-consuming to conduct the scrutiny and approval process. Eventually, the new summary format might be seen as a reasonable compromise between structured and itemized information and a free, narrative style.

In-depth analysis of the prospectus summary reform shows the pros and cons of the new solution. Without a doubt, compared to the PD regime, the advantages are: a) clarification that the summary should be read as an introduction to the prospectus, ${ }^{80} \mathrm{~b}$ ) exclusions for wholesale and base prospectuses c) the requirement that the summary is written in a non-technical manner, concise and comprehensible for investors as well as accurate, fair and not misleading, d) the format and content based on KID. However, controversies remain regarding the 7-page limit, the maximum of 15 material risk factors as well as the exclusion of cross-references and incorporations by reference. ${ }^{81}$ Although reasonable on the face of it, the new requirement for the summary to be accurate, fair and not misleading and concise might potentially cause extensive liability issues. Some scholars go even further, arguing that there should be no need for detailing the summary's scope, length and contents or even its obligatory inclusion. ${ }^{82}$

In conclusion, it remains doubtful whether issuers will welcome all the abovementioned changes with open arms. ${ }^{83}$ Having in mind the Blaise Pascal quote, "The present letter is a very long one, simply because I had no leisure to make it shorter," it might be more troublesome for them to produce a 7-pages long summary, with all the relevant information included. Especially one should bear in mind that authorities have been granted a new, wide array of excuses to refuse the prospectus approval. However, it must be noted that the new rules bring more flexibility than the overly proscriptive and immaterial summary under PD.

79 European Commission, The Commission Staff Working Document Impact Assessment..., Brussels, 30.11.2015, p. 38.

80 A. Casale, M. Bianchi, P. Spatola, op. cit.

81 Ibidem.

${ }^{82}$ L. Enriques, "EU prospectus regulation: Some out-of-the-box thinking," REVISTA LEX MERCATORIA Doctrina, Praxis, Jurisprudencia y Legislación 2017, no. 2.

83 Despite EU lawmakers assumptions that this solution will be beneficial for issuers due to the flexibility, it might, in fact, result in the opposite. 


\section{The risk factors}

\subsection{The background}

The introduction of the new and complicated risk factors regime is one of the most controversial changes of the PR, and is a justified cause for concern for the issuers. The previous PD regime described risk factors as "specific to the situation of the issuer/securities," and "material for making investment decisions." 84 However, despite these specificity and materiality tests, the risk factor disclosure has often been exploited by the issuers in order to: a) limit potential civil liability for the prospectus information. b) avoid providing clear and concise explanations of the risks. ${ }^{85}$ In fact, the regular market practice was to use vague or generic language, legal jargon, mitigating language 86 and to overload prospectuses with generic or "boiler-plate" risk factors. This tactic, being one of the most striking examples of using prospectuses as "liability shields," increased its length and practically compromised the model of investor protection, ${ }^{87}$ which was reflected in public consultations. ${ }^{88}$

The Prospectus Regulation aims to address this issue by focusing on the quality and clarity of risk factor disclosures so that a prospectus serves as a key source of pertinent information for investors. ${ }^{89}$ As the primary purpose of including risk factors in a prospectus is to ensure that investors can make an informed assessment of risks, ${ }^{90}$ the prospectus should not contain non-material and non-specific information which can undermine investor protection. ${ }^{91}$ Article 16 of the PR reforms the institution of risk factors, limiting them only to risks which are cumulatively specific to the issuer/securities, material for making an informed investment decision, as well as corroborated by the content of the prospectus. Each risk factor shall be adequately described, explaining how it affects the issuer or the securities. In addition, the PR requires the categorization of the risk factors, depending on their nature, with the most material risk factors mentioned first within each category. According to the

${ }^{84}$ See Article 2 no. 3 of Commission Regulation (EC) No 809/2004, Article 5 PD, https://eur-lex. europa.eu/legal-content/EN/TXT/PDF/?uri=CELEX:02004R0809-20130828\&from=EN (accessed: 1.08.2019).

${ }^{85}$ See para. 3 of the Final Report, ESMA Guidelines on risk factors under the Prospectus Regulation, 29 March 2019 I ESMA31-62-1217.

${ }^{86}$ E.g. lengthy descriptions of risk management policies.

${ }^{87}$ European Commission, The Commission Staff Working Document Impact Assessment..., Brussels, 30.11.2015, Annex 5, p. 39.

${ }^{88}$ See EC Consultation Document, Review of the Prospectus Directive, Brussels, 18 February 2015.

${ }^{89}$ Final ESMA Risk Factor Guidelines, para. 4.

90 Recital (54) of the PR.

${ }^{91}$ Recital (27) of the PR. 
Delegated Regulation 2019/980, ${ }^{92}$ as a rule, the risk factors section should be located after the table of contents and the summary - to make it accessible for investors.

In order to encourage an appropriate and focused disclosure of risk factors, and due to the special mandate provided in Article 16(4), ESMA developed Level 3 Guidelines on risk factors ${ }^{93}$ (published on 29 March 2019) aimed at assisting NCAs in their review of risk factors. The guidelines describe how ESMA expects competent authorities to apply the new requirements in relation to the content (specificity, materiality, corroboration) and the presentation (categorization, conciseness, the order in the prospectus summary) of risk factors. These 12 guidelines address competent authorities, ${ }^{94}$ which shall make every effort to comply 95 by incorporating them into their supervisory frameworks, ${ }^{96}$ and for their own consideration, when scrutinizing and approving a prospectus $;{ }^{97}$ alternatively, they should explain why they have refused to do so. ${ }^{98}$ A Prospectus which does not meet the rigorous PR (read with Guidelines) criteria for the risk factors, embodied in the PR and the Guidelines, shall be challenged by the NCA. ${ }^{99}$ This should result in a discussion between the authority and the person responsible for the prospectus who, eventually, shall be allowed to respond or to amend the disclosure, as appropriate. However, if this person fails to do so, the NCA should use its powers pursuant to Article 20 to ensure compliance with Article 16. Under the initial version of the ESMA document, national authorities were obliged to simply not approve prospectuses incompatible with the guidelines. ${ }^{100}$

92 Commission Delegated Regulation 2019/980 of 14 March 2019 supplementing Regulation (EU) 2017/1129 of the European Parliament and of the Council as regards the format, content, scrutiny and approval of the prospectus to be published when securities are offered to the public or admitted to trading on a regulated market, and repealing Commission Regulation (EC) No 809/2004.

93 Final Report, ESMA Guidelines on risk factors under the Prospectus Regulation, 29 March 2019 I ESMA31-62-1217, https://www.esma.europa.eu/sites/default/files/library/esma31-62-1217_ final_report_on_guidelines_on_risk_factors.pdf(accessed: 1.08.2019). See also a consultation paper dated 13 July 2018, https://www.esma.europa.eu/sites/default/files/library/esma31-62-996_consultation_paper_on_guidelines_on_risk_factors.pdf (accessed: 1.08.2019).

${ }^{94}$ However, naturally, persons responsible for the prospectus should consider these guidelines when preparing a prospectus for submission to the relevant competent authority.

$9516(3)$ of the ESMA Regulation.

96 Para. 8 of the Annex to Final ESMA Risk Factor Guidelines.

97 Article 20 of the PR.

98 Para. 10 of the Annex to Final ESMA Risk Factor Guidelines.

${ }^{99}$ See para. 14 of the Annex to Final ESMA Risk Factor Guidelines. However, when challenging the comprehensibility of risk factor disclosure, NCAs may take into account the type of targeted investor to whom the prospectus is addressed (i.e. whether the securities have a denomination per unit of at least EUR100,000, or the securities are to be traded only on a regulated market, accessible only to qualified investors). See para. 15 of the Annex to Final ESMA Risk Factor Guidelines.

$100 \mathrm{https}: / / w w w . a s h u r s t . c o m / e n / n e w s-a n d-i n s i g h t s /$ legal-updates/esma-publishes-guidelines-onrisk-factors-under-the-new-prospectus-regulation/ (accessed: 1.08.2019). 


\subsection{New risk factors requirements}

The specificity test means that a clear and direct link ${ }^{101}$ between the risk factor and the relevant issuer ${ }^{102}$ or securities is required. ${ }^{103}$ Environmental, social and governance circumstances ${ }^{104}$ should be taken into account as long as there is a potential specific negative impact they can have on the issuer. Generic or "boiler-plate" risk factors should be avoided. ${ }^{105}$ Although the same industry issuers or same type securities may be exposed to similar risks, whenever specific risks may affect issuers differently, these differences should be reflected. Even potential interdependencies of risk factors should be reflected. Disclaimer-like risk factor disclosure ${ }^{106}$ (serving as a liability shield) is not typically specific about the issuer, guarantor, nor is it security-specific, as it obscures the specificity and materiality of a risk factor. Risk factors should also not merely be copied from other documents. ${ }^{107}$

The materiality of a risk factor is defined as a combination of the probability of its occurrence and the expected magnitude of their negative impact. ${ }^{108}$ The materiality of the risk factors may be demonstrated by quantitative information $^{109}$ or, the qualitative scale of low, medium or high, although both methods are voluntary. ${ }^{110}$ Mitigating language (such as lengthy and detailed descriptions of risk management policies) is not prohibited but can only be used to illustrate the probability of the occurrence or expected magnitude of negative impact, provided that it does not compromise the materiality of risk factors. ${ }^{111}$ Whenever materiality of the risk factor is not clear and apparent from the disclosure, the potential negative impact is not disclosed, or the inclusion of mitigating language compromises the materiality, the NCA should challenge the prospectus. ${ }^{112}$ According to its in-

101 Guideline (1).

102 Specificity related to the issuer/guarantor may depend on the type of entity (e.g. startup companies, regulated entities, specialist issuers etc.).

${ }^{103}$ Specificity related to the type of security may depend on the characteristics of the security. For example: the degree of liquidity of securities, the subordination of the securities (in the case of securities issued by credit institutions that are subject to bail-in under Directive 2014/59/EU) and exchange rate risks. See K. Wöckener et al., "The new risk factor regime under the prospectus regulation," White and Case Client Alert 2019, https://www.whitecase.com/publications/alert/new-risk-factor-regime-under-prospectus-regulation (accessed: 1.08.2019).

${ }^{104}$ Recital (54).

105 Para. 16-20 Annex to Final ESMA Risk Factor Guidelines.

106 Guideline (2).

107 Para. 23 of the Annex to Final ESMA Risk Factor Guidelines.

108 Article $16(1)(2)$ of the PR.

109 Such information may be available in previously published documents such as management reports, financial statements, ad-hoc-disclosures etc.

110 See Article 16 (1)(3) and para. 26-27 of the Annex to Final ESMA Risk Factor Guidelines.

111 See Guideline (5) and para. 29-30 of the Annex to Final ESMA Risk Factor Guidelines.

112 See Guidelines (3-5). 
itial document, ${ }^{113}$ ESMA proposed the definition of materiality known from para. 2.11 of the International Financial Reporting Standards Conceptual Framework (information is material if omission or misstatement could influence investment decisions based on the use of the prospectus). Fortunately, after many respondents expressed concern that it will lead to confusion ${ }^{114}$ when reading with Article 16(1), the standard of materiality embodied in Article 6(1) has been retained. ${ }^{115}$ According to ESMA, ${ }^{116}$ given the lack of formal definition of materiality, the criteria set up in Article 16(1) are the most relevant. Commenting on the initial ESMA proposal, respondents to the consultation expressed concerns over alleged authority competence to assess the specificity and materiality of risk factors. ${ }^{117}$ However, in the final version, competent authorities are not required to assess the specificity or materiality of a risk factor as it is the responsibility of the issuer. ${ }^{118}$ Still, the competent authority should ensure that the specificity and materiality of the risk factor is apparent and clearly demonstrated from the disclosure of the risk factor, provided by the issuer.

As mentioned, according to the corroboration requirement, the materiality and specificity of the risk factor should be corroborated by the overall picture presented by the prospectus. ${ }^{119}$

The presentation of risk factors across categories (depending on their nature) should support their comprehensibility and aid investors in navigating the risk factors section. ${ }^{120}$ Only the single, most material risk factor has to be presented first in each category. The Guidelines specify the exemplary categories into which risk factors, specific and material to the issuers ${ }^{121}$ and securities, ${ }^{122}$ could be divided. The categories shall be identified via the use of appropriate headings, and should only be further divided into sub-categories in cases where it can be clearly justified

113 See para. 27 of the Consultation Paper on Guidelines on Risk Factors under the Prospectus Regulation.

114 Para. 36, 40 of the Annex.

115 It requires prospectuses to contain the necessary information material for investors to make an informed assessment of: the assets and liabilities, profits and losses, financial position and prospects of the issuer; the rights attaching to the securities; and the reasons for the issuance and its impact on the issuer.

116 Para. 40 Final ESMA Risk Factor Guidelines.

$117 \mathrm{https} / /$ www.ashurst.com/en/news-and-insights/legal-updates/esma-publishes-guidelines-onrisk-factors-under-the-new-prospectus-regulation/ (accessed: 1.08.2019).

118 Para. 21 and 25 of the Annex.

119 See Guideline (6), Article 16 of the PR.

${ }^{120}$ See Guidelines (7-10).

121 Risks related to the issuer's financial situation; risks related to the issuer's business activities and industry; legal and regulatory risk; internal control risk; environmental, social and governance risks.

122 Risks related to the nature of the securities; risks related to the underlying; risks related to the guarantor and the guarantee; risks related to the offer to the public and/or admission of the securities to trading on a regulated market. 
based on the particular prospectus. The suggested number of (sub) categories in the prospectus is 7 but should not exceed $10^{123}$ as it would be disproportionate to the size/complexity of the transaction and risk to the issuer.

Moreover, to prevent "size inflation" of prospectuses, the NCAs have to ensure a concise form of the disclosure and, if necessary, challenge the length of the risk factors disclosure. ${ }^{124}$ The disclosure of risk factors in the summary should be consistent with the order of the risk factors section in a prospectus but it does not have to include risk factors from all of the categories included in a prospectus. ${ }^{125}$ Interestingly, the ESMA final guidelines include several non-exhaustive examples of adequately formulated risk factors.

In terms of risk factors disclosure, the new regime seems to be at least partially modeled on the US approach. Under $\S 229.105$ (Item 105) of the Regulation S-K, the registrants should discuss, in a concise and logically organized way (with sub captions), the most significant factors that make an investment in the registrant. Similarly to the EU regime, generic risks should be avoided, and the placement of the risk factor discussion must immediately follow the summary section, the cover page of the prospectus, or the pricing information. Moreover, the registrant must furnish this information in plain English and in accordance with $\S 230.421$ (d) of Regulation $\mathrm{C}$, which provides guidelines with regards to general standards of information presentation in prospectuses. ${ }^{126}$ Similarly, calling out negative practices, such as "mitigating language" (e.g., clauses that begin with "while," "although" or "however"), "size inflation,"127 vague "boilerplate" explanations or generic risk factors has also been a long-lasting domain of the SEC. ${ }^{128}$

However, unlike in the EU, in the US there are no formal materiality, specificity, corroboration requirements. There is also no indication to arbitrarily assess the materiality of risk factors based on the probability of their occurrence and the expected magnitude of their negative impact (let alone using quantitative or vague qualitative terms). There are no limits to the number of factors, and no requirement to discretionally pick up the most material risk within each category.

${ }^{123}$ In the case of a standard, single-issuer, single-security prospectus. In other circumstances, such as in the case of multi-product base prospectuses larger number may be appropriate.

124 Guideline (11).

125 Guideline (12).

126 Inter alia: a) The information required in a prospectus shall be set forth in such fashion as not to obscure any of the required information from being complete or not misleading; b) Information should be presented in a clear, concise and understandable manner. Sections and descriptive headings should be used, glossaries and legal and highly technical business terminology shall be avoided; c) To enhance the readability of the prospectus, plain English principles in the organization, language, and design of cover pages, the summary, and the risk factors section should be used.

127 See Note to $\S 230.421(\mathrm{~B})$.

128 See R.S. Panasar et al., op. cit., pp. 9-10; see also SEC Division of Corporation Finance, Staff Observations in the Review of Smaller Reporting Company IPOs, https://www.sec.gov/divisions/ corpfin/guidance/cfsmallcompanyregistration.htm (accessed: 1.08.2019). 
Also, the prospectus summaries in the US lack similar requirements when it comes to length and number of risk factors. This is $\mathrm{n}$ ot to mention the fact that specific risk factor examples ${ }^{129}$ enumerated in the former Item 503(c) of the Regulation S-K (unchanged since $1964^{130}$ ) have lately been eliminated under the FAST Act Modernization and Simplification of Regulation $\mathrm{S}-\mathrm{K}^{131}$ to enhance the principles-based notion of the risk factors disclosure and to encourage registrants to focus on their own risk identification processes. ${ }^{132}$ In conclusion, the new PR rules, followed by the ESMA guidelines, are far more specific and complicated, thus less flexible and stiffer than their US counterparts. This is especially worrying in light of the clear sanctions available to the NCAs, such as challenging the prospectus, or refusing to approve it.

\subsection{Consequences and controversies}

The introduction of certain highly complicated and prescriptive requirements with regards to the risk factors is of concern to the issuers, firstly because it might impede and lengthen the approval process, and secondly, it exposes them to civil liability expost. It will be difficult and time-consuming for the issuers to meet the new combined requirements of specificity and materiality, as they will have to tailor to their needs every risk factor with extreme caution, trying to discretionally assess its probability of occurrence, expected magnitude of negative impact and somehow express its materiality quantitatively or qualitatively. It can be expected that issuers will avoid using qualitative means of describing risk factors, to mitigate liability exposure- in case lower-rated risk factors materialize. ${ }^{133} \mathrm{~A}$ formal crackdown on mitigating language could also be problematic. Although mitigating language itself can be included to illustrate the probability of occurrence or expected magnitude of a negative impact (as long as it does not compromise the materiality), issuers will find themselves between a rock and a hard place and often will choose to avoid mitigating language at all costs in order to save time on useless negotiations with the NCA.

${ }^{129}$ Namely, a registrant's lack of an operating history; a registrant's lack of profitable operations in recent periods; a registrant's financial position; a registrant's business or proposed business; the lack of a market for a registrant's common equity securities or securities convertible into or exercisable for common equity securities.

${ }^{130}$ See: Guides for Preparation and Filing of Registration Statements, Release No. 33-4666 (Feb. 7, 1964) [29 FR 2490 (Feb. 15, 1964)].

131 The final rules became effective May 2, 2019.

132 Commenters generally agreed that the examples were not helpful as being written too generically. The SEC feared that these examples suggested that a registrant must address each one in its risk factor disclosures, regardless of the significance to its business. Instead, registrants should provide risk disclosure that is more precisely calibrated to their particular circumstances and therefore more meaningful to investors.

${ }^{133}$ S. Bullock et al., op. cit., p. 3. 
Similar problems arise concerning the categorization requirement. Issuers may feel pressured to pick up only the most "correct" and most material risk factor from each category. In order to do so, they will definitely struggle to assess materiality quantitatively or qualitatively, as well as comparing high probability risk factors with a lower direct impact (new competitors, technological advancements) versus low probability risk with a high negative effect (crisis in the sector, trade war, natural disaster - if a production line is located in the seismic zone or tsunami risk zone). ${ }^{134}$ Issuers might be worried by the NCAs, markets and frustrated, compensation-seeking investors reaction if the financial loss is caused by none of the highlighted risks.

Even the corroboration requirement is not free from controversy. Even though the guidelines allow for the demonstration of the direct and clear corroboration of the materiality and specificity by the overall picture demonstrated by the prospectus, issuers are likely to include a great number of repetitions in order to shield themselves from the prospectus being challenged by the NCAs. Some argue that issuers might be additionally concerned by the NCAs view on the risks being a strength at the same time (e.g., a single lucrative contractor, temporary fashion habits, strong and loyal customer base). ${ }^{135}$

Adhering to the ESMA guidelines, NCAs may have the profound impression that they should challenge the prospectus even if the tiniest inconsistency occurs. Consequently, issuers will have an ongoing impression of the sword of Damocles hanging over their heads. In the case of a challenge, the discussion between the NCA and issuer, preceding the approval of the prospectus, will more likely look like a full-blown and timely negotiation over content and presentation of each and every risk factor. Although the issuer is the one subject to potential liability, the NCAs will have the final say when it comes to the assessment of fulfilling the requirements - which may seem too arbitrary or even redundant. Lastly, it is very doubtful whether the issuer would be able to successfully defend himself against investors when some risk factors were removed, replaced or reformulated under the NCAs heavy pressure. In other words, the arbitrary and highly inquisitional approach of the NCAs can not only prevent issuers from presenting their risk assessment as they would like, but also limit their protection from the wave of frivolous claims in case of investors loss. As in other matters, this may plausibly lead to a situation where the EUs most powerful NCAs approach will be unconsciously followed by other, less influential ones - often regardless of the specificity of local markets. In practice, the market pressure alongside with the NCAs new omnipotence can force issuers to include and formulate certain risk factors against their will in order to save time and due to unprecedented liability concerns, and consequently, might result in the exit of smaller market players from the capital markets.

134 R.S. Panasar et al., op. cit., p. 9.

135 Ibidem. 
The desire of prospectus-liable persons to shield themselves from civil claims at all costs is especially justifiable in the face of lack of a harmonized European liability regime. ${ }^{136}$ In addition, when it comes to cross-border offerings, it is hard to predict which country laws will be governing potential investor claims. In particular, the different risk factors regimes and liability standards in the US and the EU can also become a discouraging factor for some issuers. ${ }^{137}$ Taking this into consideration, the costs and time of preparing the risk factors section might rise substantially with relatively modest benefit for the investors, who rarely analyze this information.

\section{Conclusion}

Alongside the flagship and mostly positive changes, such as raising the prospectus exemption thresholds and creating new types of prospectuses, the Regulation introduces also a number of more questionable changes. First, it eradicates the autonomous notion of the private offering or private placement by de facto incorporating private offers to the broad notion of public offer. Secondly, despite severe liquidity concerns, it extends the alleviated wholesale disclosure regime to all non-equity securities, provided that they are traded only on a regulated market, accessible exclusively to qualified investors. Third, it limits both the prospectus summary's length and number of risk factors, which raises issuers' liability concerns. Fourth, the new regime reforms the risk factors section, by introducing extensive and detailed requirements and guidelines on materiality, specificity, corroboration and categorization, which potentially carries a reasonable risk of approval delays as well as overmuch liability exposure for the issuers. Seemingly less prominent or even "minor," these changes can nonetheless have a significant impact on issuers and investors in the European Union.

Moreover, it is regrettable that the reform is not complete, as some points are still missing. Most importantly, one of the reform's biggest defects is the lack of a new harmonized European liability regime. ${ }^{138}$ When it comes to cross-border offerings, it is still hard to predict which country laws will be governing potential investor claims. Additionally, the scrutiny process could have been more harmonized ${ }^{139}$ and the universal European prospectus could have been introduced ${ }^{140}$ as a remedy for divergencies between national regimes and the NCAs approaches. Companies could have been also granted more flexibility when it comes to choosing the Home Member State. ${ }^{141}$

$136 \mathrm{https} / /$ www.ashurst.com/en/news-and-insights/legal-updates/esma-publishes-guidelines-onrisk-factors-under-the-new-prospectus-regulation/ (accessed: 1.08.2019).

137 R.S. Panasar et al., op. cit., p. 10.

138 https://www.ashurst.com/en/news-and-insights/legal-updates/esma-publishes-guidelines-onrisk-factors-under-the-new-prospectus-regulation/ (accessed: 1.08.2019).

139 A. Casale, M. Bianchi, P. Spatola, op. cit.

140 Ibidem.

141 Ibidem. 
Furthermore, some argue that the whole approach to the problem should be revisited and more radical steps taken in order to improve the efficiency of the primary markets. They point to evidence suggesting that disclosure is of little help to retail investors when it comes to improving investment choices. ${ }^{142}$ Additionally, the role of the disclosure and prospectus pre-approval process in blocking fraud and amateurish initiatives is believed to be only of limited use. ${ }^{143}$ According to L. Enriques, there are much better solutions that can be introduced in order to enhance the prospectus regulation. ${ }^{144} \mathrm{He}$ even proposes to abandon current itemized disclosure and securities regulators' pre-approval of the prospectus based on the assumption that issuers will not dare to hide price-sensitive information- or lose investors. Some experts also propose the replacement of the whole prospectus with the Key Information Document ('KID') based on PRIIPS, ${ }^{145}$ which would however require more determination from EU lawmakers.

In conclusion, the PR cannot be considered the revolution it was expected to be. Some experts call it more of a missed opportunity. It seems that despite the fact that PR is generally a modest step in the right direction, some changes might downplay its positive impact or even be counter-productive, as the social benefit will be lower than the social cost resulting from additional administrative burdens placed upon issuers. Some solutions proposed by the PR are too cautious and not ambitious enough, as the reform of the EU capital markets requires definitely more revolutionary and ground-breaking measures in order to compete with more efficient and booming capital markets, such as those in the United States or Asia.

In my opinion, there is still a growing need to propose a landmark and original vision of the framework of the prospectus obligations in public offerings so they can best address the particular needs of numerous market players - including companies' need for cheap and easy funding, the need for appropriate investor information protection, and finally - the general need to increase the competitiveness and attractiveness of the EU Capital Markets Union. Appropriate solutions and legal policy in this area would not only contribute to strengthening and increasing capitalization of the markets, but also promote the sector of SMEs, and consequently - help to unlock the deeply hidden growth potential for the entire European Union economy.

Despite the fact that the major issues of the public offerings market have been properly identified, the European legislator lacked the courage to use momentum and to fully follow international trends in the field of liberalization of prospective obligations. Given that the US is undergoing another reform of prospect duties, the

142 N. Moloney, How to Protect Investors, Cambridge 2010, pp. 291-296.

143 J. Armour et al., Principles of Financial Regulation, Oxford 2016.

${ }^{144}$ According to L. Enriques: a) the price of the offer to the public shall not exceed the price set for the offering reserved to institutional investors; b) mandatory disclosures should cover the kind of information that securities analysts really find relevant; c) there should be no specific requirements regarding the shape and content of the prospectus summary or risk factors.

${ }^{145}$ L. Enriques, op. cit.; A. Casale, M. Bianchi, P. Spatola, op. cit. 
PR should be seen as a missed opportunity. It seems that in times of the aggressive phenomenon of Regulator Shopping, some European lawmakers should bear in mind that if we stand still or move too slowly, it means that we move backward. Only time and legal practice will show to what extent the prospectus reform will contribute to increasing the efficiency and attractiveness of European capital markets.

\section{References}

\section{Legal acts}

Capital Markets Union - Communication of the Commission of 30 September 2015, entitled Action Plan on Building a Capital Markets Union.

Commission Delegated Regulation (EU) 2019/979 of 14 March 2019 supplementing Regulation (EU) 2017/1129 of the European Parliament and of the Council with regard to regulatory technical standards on key financial information in the summary of a prospectus, the publication and classification of prospectuses, advertisements for securities, supplements to a prospectus, and the notification portal, and repealing Commission Delegated Regulation (EU) No 382/2014 and Commission Delegated Regulation (EU) 2016/301.

Commission Delegated Regulation (EU) 2019/980 of 14 March 2019 supplementing Regulation (EU) 2017/1129 of the European Parliament and of the Council as regards the format, content, scrutiny and approval of the prospectus to be published when securities are offered to the public or admitted to trading on a regulated market, and repealing Commission Regulation (EC) No $809 / 2004$.

Directive 2003/71/EC of the European Parliament and of the Council of 4 November 2003 on the prospectus to be published when securities are offered to the public or admitted to trading and amending Directive 2001/34/EC.

Directive 2010/73/EU of the European Parliament and of the Council of 24 November 2010 amending Directives 2003/71/EC on the prospectus to be published when securities are offered to the public or admitted to trading and 2004/109/EC on the harmonisation of transparency requirements in relation to information about issuers whose securities are admitted to trading on a regulated market (Text with EEA relevance).

Esma/2013/619 Document, Report on Comparison of liability regimes in Member States in relation to the Prospectus Directive, 30.05.2013.

ESMA 31-62-1193 Document (issued 8.02.2019).

ESMA Consultation paper dated 13 July 2018, https://www.esma.europa.eu/sites/default/files/library/esma31-62 996_consultation_paper_on_guidelines_on_risk_factors.pdf.

ESMA's Guidelines on Alternative Performance Measures.

ESMA's report Investment-based crowd-funding: insights from regulators in the EU of May 2015.

European Commission, The Commission Staff Working Document Impact Assessment accompanying the document Proposal for a Regulation of the European Parliament and of the Council on the prospectus to be published when securities are offered to the public or admitted to trading, Brussels, 30.11.2015.

European Commission, The Commission Staff Working Document, Feedback Statement for the Public Consultation on the Capital Markets Union, Mid- Term Review Accompanying the document Communication from the Commission to the European Parliament, the Council, the European Economic and Social Committee and the Committee of the Regions on the Mid-Term Review of the Capital Markets Union Action Plan, Brussels, 8.06.2017. 
European Commission, The Commission Staff Working Document Impact Assessment accompanying the document Proposal for a Regulation of the European Parliament and of the Council amending Regulation (EU) No 596/2014 and (EU) 2017/1129 as regards the promotion of the use of SME growth markets, Brussels, 24.05.2018.

The European Commission's regulatory fitness and performance (REFIT) programme, https://ec.europa.eu/info/law/law-making-process/evaluating-and-improving-existing-laws/refit-making-eulaw-simpler-and-less-costly_en.

Final Report, ESMA Guidelines on risk factors under the Prospectus Regulation, 29 March 2019 , I ESMA31-62-1217.

Guides for Preparation and Filing of Registration Statements, Release No. 33-4666 (Feb. 7, 1964) $[29$ FR 2490 (Feb. 15, 1964)].

Regulation (EU) 2017/1129 of the European Parliament and of the Council of 14 June 2017 on the prospectus to be published when securities are offered to the public or admitted to trading on a regulated market, and repealing Directive 2003/71/EC.

SEC Division of Corporation Finance, Staff Observations in the Review of Smaller Reporting Company IPOs, https://www.sec.gov/divisions/corpfin/guidance/cfsmallcompanyregistration.htm.

The US Securities Act of 1933.

The US Securities Exchange Act of 1934.

The US Regulation S-K.

\section{Secondary sources}

Anderson N. et al., "A European capital markets union: Implications for growth and stability,” Bank of England Financial Stability Paper 2015, no. 33.

Armour J., Awrey D., Davies P., Enriques L., Gordon J., Mayer C., Payne J., Principles of Financial Regulation, Oxford 2016.

Behavioral Patterns and Pitfalls of U.S. Investors, A Report Prepared by the Federal Research Division, Library of Congress under an Interagency Agreement with the SEC, August 2010.

Bullock S., Delgado A., Morris T.,Chambers C., New Prospectus Regulation: An Evolving Regime, Ashurst LLP Paper, 2017 Thomson Reuters (Professional) the UK.

Casale A., Bianchi M., Spatola P., "The new prospectus regulation: A missed opportunity?," Oxford Business Law Blog, 2017, https://www.law.ox.ac.uk/business-law-blog/blog/2017/03/new-prospectus-regulation-missed-opportunity.

Çelik S., Demirtaş G., Isaksson M., "Corporate bonds, bondholders and corporate governance," OECD Corporate Governance Working Papers 2015, no. 16.

Chyla Ł., "New prospectusr egime: A critical analysis of chosen key changes," Studenckie Prace Prawnicze, Administratywistyczne i Ekonomiczne 28, 2019.

Chyla Ł., "Is 2.5 million EUR prospectus exemption threshold enough?," Przeglad Prawno-Ekonomiczny 2019, no. 47.

Demyanyk Y., Ostergaard C., Sørensen B.E., "Risk sharing and portfolio allocation in EMU,” DG ECFIN Economic Paper 2008, no. 334.

Enriques L., "EU prospectus regulation: Some out-of-the-box thinking," REVISTA LEX MERCATORIA Doctrina, Praxis, Jurisprudencia y Legislación 2017, no. 2.

Femminis G., "Risk-sharing and growth: The role of precautionary savings in the 'education' model," Scandinavian Journal of Economics 103, 2001.

Fox M.B., "Initial public offerings in the capital markets union: A US perspective," [in:] D. Busch, E. Avgouleas, G. Ferrarini, Capital Markets Union in Europe, Oxford 2018.

Howell E., "An analysis of the prospectus regime: The EU reforms and the 'Brexit' factor," European Company and Financial Law Review 15, 2018, no. 1. 
Moloney N., How to Protect Investors, Cambridge 2010.

Moloney N., Ferran E., Payne J. (eds.), The Oxford Handbook of Financial Regulation, Oxford 2015.

Möllers T.M.J., Kernchen E., "Information overload at the capital market," Europa e Diritto Privato 2010, no. 4.

Nowosad W., "Nowe rozporządzenie prospektowe - analiza wybranych zmian legislacyjnych," Przeglad Prawa Handlowego 2018, no. 10.

Obstfeld M., "Risk-taking, global diversification, and growth," American Economic Review 84, 1994, no. 5.

Panasar R.S., Healy J., Collar K., Legein L., Bourguignon G., Verhulst G., Apfelbacher G., Metzner M., Pfisterer V., "The new prospectus regulation - the story so far," Cleary Gottlieb Alert Memorandum 7.03.2019.

Pietrancosta A., Grottes A.M. des, "Has the notion of 'private offerings' been abolished by the prospectus regulation of 14 june 2017?," Bulletin Joly Bourse 2018, no. 1.

Wöckener K., Gargaro C., Hauman M., "The new risk factor regime under the prospectus regulation," White and Case Client Alert 2019, https://www.whitecase.com/publications/alert/ new-risk-factor-regime-under-prospectus-regulation.

\section{Internet sources}

https://www.ashurst.com/en/news-and-insights/legal-updates/esma-publishes-guidelines-on-riskfactors-under-the-new-prospectus-regulation/.

http://www.elexica.com/en/legal-topics/equity-capital-markets/160319-new-prospectus-regime.

https://www.nortonrosefulbright.com/en/knowledge/resources-and-tools/capital-markets-union/ prospectus-regulation. 